\title{
A serious game to foster historical heritage memory
}

Sandro J. Rigo, Vinicius Cassol, João Bittencourt, Fernando Marson, Pedro Rossa Applied Computing Graduate Program (Pipca) - University of Vale do Rio dos Sinos (Unisinos), São Leopoldo, Brazil \{rigo.vjcassol, joaorb, fmarson\}@unisinos.br, pedrorossa.tro@gmail.com

\begin{abstract}
This project objectives are to promote the creation of digital games as innovative products aligned to the content and new media industry, related to activities linked to cultural and historic heritage site in the south of Brazil. To achieve these goals were created innovative digital products, which applies advanced interaction devices, targeted to young students.
\end{abstract}

Keywords: Serious games, historical monuments, education.

\section{Introduction}

This project aims to develop serious games [1] as support to History teaching [2], through the creation of digital games as innovative products aligned to the content and new media industry, related to activities linked to a cultural and historic heritage site in the south of Brazil.

To achieve these goals were created innovative digital products, which applies advanced interaction devices, targeted to platforms adequate to the expected audience, formed by young students. Beyond this, several events and activities such as lectures and hands-on workshops for the creation of digital products to diverse audiences are being carried out. So far the project has been in contact with ten schools and also supports the production of education material about indigenous history and culture. Finally, the promotion of tourism in the cultural and historic heritage site of "Missões Jesuíticas" [3] is expected, as long as the promotion of technology transference from the University to the productive sector.

Figure 1 shows the initial interface of the developed game, which consists of five topics representing relevant aspects of the indigenous culture in Jesuitic Missions.
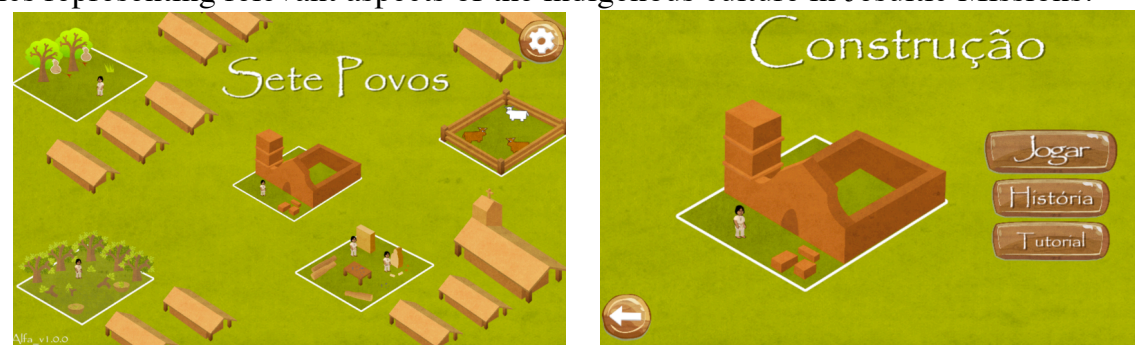

Fig. 1. The web interface of the game

Creative digital entertainment solutions linked to facts and historical sites relate directly to the school context, linking the education agenda in two vertices associated to learning. The first one is the technology as a suitable and relevant tool. The second is the playful space of the game as background. These two aspects combine especially to the teaching of history of Brazil in the Jesuit theme, since the offer of artifacts and materials available is quite scarce. The figure 2 shows the mobile device version of 
V Congresso Brasileiro de Informática na Educação (CBIE 2016)

Anais dos Workshops do V Congresso Brasileiro de Informática na Educação (CBIE 2016)

the game, in which is exemplified a training camp. Each part of the game has some instructions, in a tutorial referring to the gameplay, and also a resume of historical aspects regarding that particular situation. Therefore, we intend to stimulate both the ludic aspects and the historical ones. More detailed historical information is indicated to the students in the project web site (http://www.unisinos.br/game-das-missoes).
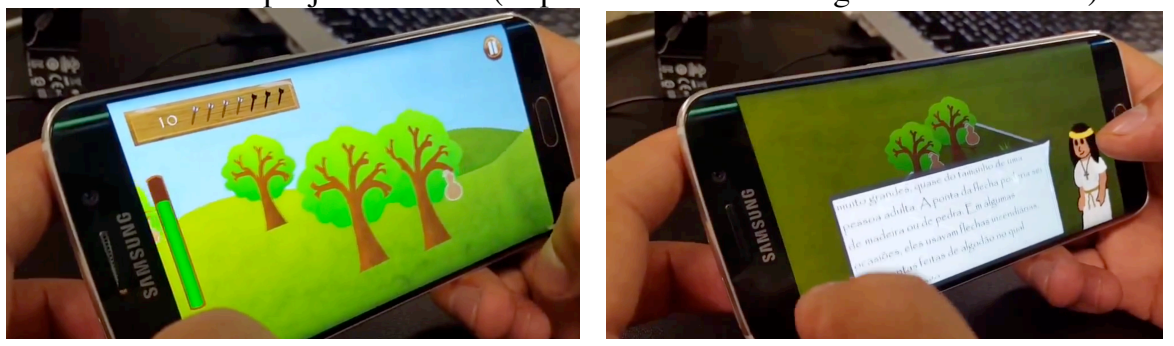

Fig. 2. Mobile interface of the game and historical information to the students.

The figure 3 illustrates a virtual reality version of some of the game components. In this case is exemplified the training camp, that in this version consists of an application that integrates a device capable of generating various sensors stimulus from an Arduino device attached to a bow, that are sent to a visualization application in a mobile phone that is used by the gamer with a beenoculus device.
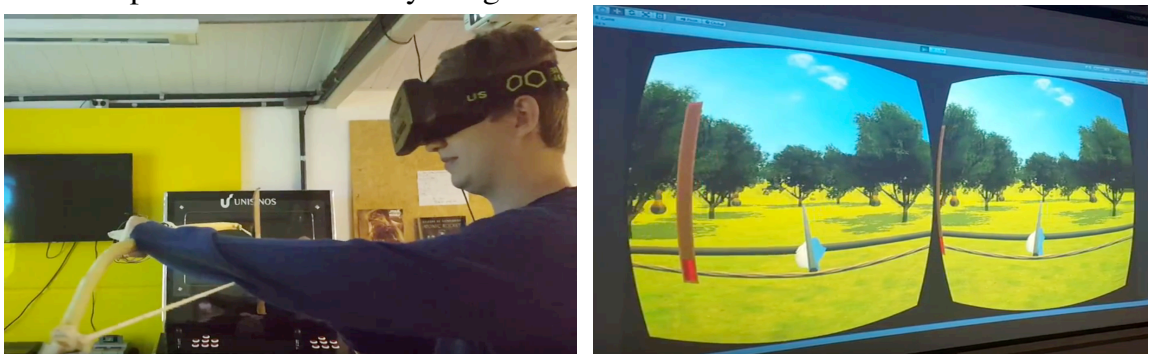

Fig. 3. Virtual reality version of a part of the game: training camp.

\section{Final remarks}

The project developed relevant interaction with schools, through activities for students and teachers, such as the use of digital games about the historical context of the Jesuit missions. Some examples are workshops for creation of digital games and workshops with history teachers (and other areas) of elementary school, discussing possibilities of classroom experience from the digital games produced. These workshops presents and discusses the context of Jesuit missions and also the usage scenario of digital games in the classroom. The games developed and their use in schools linked to the project are used as a starting point for this analysis.

\section{References}

1. Michael, D., Chen, S. Serious Games: Games That Educate, Train and Inform. Boston: Thomson. 2006

2. Andrade, D., o lúdico c o sério: experiências com jogos no ensino de história . História e Ensino, 1, Londrina, v.13, p.91-106, set.2007 
V Congresso Brasileiro de Informática na Educação (CBIE 2016)

Anais dos Workshops do V Congresso Brasileiro de Informática na Educação (CBIE 2016)

3. Neto, M. A utopia possível : as missões jesuíticas em Guairá. Seu suporte econômicoecológico", Rio de Janeiro : IHGB. 2013. 